\title{
DÜBLIN
}

Technological University Dublin

ARROW@TU Dublin

\section{Controlling Brochothrix Thermosphacta as a Spoilage Risk Using in Package Atmospheric Cold Plasma}

\author{
Apurva Patange \\ Technological University Dublin \\ Daniela Boehm \\ Dublin Insitute of Technology, daniela.boehm@tudublin.ie \\ Carmen Bueno-Ferrer \\ Technological University Dublin
}

See next page for additional authors

Follow this and additional works at: https://arrow.tudublin.ie/schfsehart

Part of the Environmental Public Health Commons, Food Microbiology Commons, and the Pathogenic Microbiology Commons

\section{Recommended Citation}

Patange, A., Boehm, D., Bueno-Ferrer, C., Cullen, P.J., Bourke, P., 2017. Controlling Brochothrix thermosphacta as a spoilage risk using in-package atmospheric cold plasma, Food Microbiology. doi:10.1016/j.fm.2017.04.002

This Article is brought to you for free and open access by the School of Food Science and Environmental Health at ARROW@TU Dublin. It has been accepted for inclusion in Articles by an authorized administrator of ARROW@TU Dublin. For more information, please contact arrow.admin@tudublin.ie, aisling.coyne@tudublin.ie, gerard.connolly@tudublin.ie.

Funder: European Community's Seventh Framework Program (FP7/2207-2013)

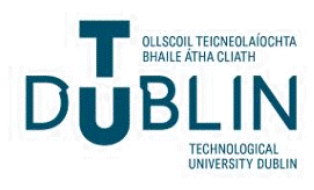




\section{Authors}

Apurva Patange, Daniela Boehm, Carmen Bueno-Ferrer, Patrick Cullen, and Paula Bourke

This article is available at ARROW@TU Dublin: https://arrow.tudublin.ie/schfsehart/252 


\section{Correspondence:}

8 Paula Bourke, Dublin Institute of Technology, Cathal Brugha Street, Dublin 1, Ireland.

9 Tel: +353-14027594; Fax: +353-14024495;

10

\section{Controlling Brochothrix thermosphacta as a spoilage risk using in} package Atmospheric Cold Plasma

\author{
Apurva Patange ${ }^{1}$, Daniela Boehm ${ }^{1}$, C. Bueno-Ferrer ${ }^{1}$, P.J. Cullen ${ }^{2}$ and Paula Bourke ${ }^{1 *}$.
}

1. Plasma Research Group, School of Food Science and Environmental Health, Dublin Institute of Technology, Ireland

2. School of Chemical Engineering, UNSW, Sydney, Australia

E-mail: paula.bourke@dit.ie 


\section{Abstract}

12 Brochothrix thermosphacta is a predominant spoilage microorganism in meat and its control

13 in processing environments is important to maintain meat product quality. Atmospheric cold

14 plasma is of interest for control of pathogenic and spoilage microorganisms in foods. This

15 study ascertained the potential of dielectric barrier discharge atmospheric cold plasma (DBD-

$16 \mathrm{ACP}$ ) for control of B. thermosphacta in response to key parameters such as treatment time,

17 voltage level, interactions with media composition and post treatment storage conditions.

18 Challenge populations were evaluated as suspensions in PBS, as biofilms in meat model

19 medium and surface attached on raw lamb chops under MAP.

20 ACP treatment $(80 \mathrm{kV})$ for 30 s inactivated $B$. thermosphacta populations below detection in

21 PBS, while 5 min treatment achieved a 2 Log cycle reduction using a complex meat model medium and attached cells, suggesting useful control for meat processing facilities. A 'worst case scenario challenge' of high population density on a nutritious medium in a biofilm matrix was evaluated using a surface inoculated lamb chop and the antimicrobial efficacy of plasma was reduced but still apparent over the 10 day storage period. However, there is scope to further enhance microbial control leading to meat storage life extension through adjusting the modality of treatment.

Keywords: Brochothrix thermosphacta, atmospheric cold plasma (ACP), meat model, lamb chop, biofilm, planktonic cells. 
There has been an increase in consumption and demand for meat and meat products among consumers globally (Eblex, 2014). Sustainable meat production is multi-faceted, but one aspect is shelf-life extension which requires the maintenance of both microbiological safety and quality within an extended shelf life to facilitate access to international markets. Major challenges exist for the safe extension of shelf life of fresh meat and compliance with microbiological criteria in different regions (Adams and Moss, 2000). A rich nutrient composition, high water content (>0.98) and $\mathrm{pH}$ 5.0-6.5 makes meat an ideal environment for the rapid growth of several micro-organisms (Nowak et al., 2011).

B. thermosphacta is one of the most common food spoilage causing agents, usually growing on raw food, lightly preserved meat products and meat processing facility surfaces (Nychas et al., 2008). Its ability to survive and grow in the otherwise challenging environments implemented in meat processing and preservation indicate the need for alternative decontamination and control measures. It is a facultative anaerobe able to tolerate growth at variable temperature of $0-30^{\circ} \mathrm{C}, \mathrm{pH}$ 5-9 (Collins-Thompson and Lopez, 1980), within a water activity range of $0.94-0.99$ (Gardner, 1981), and tolerates up to $10 \% \mathrm{NaCl}$ (Gribble and Brightwell, 2013; Erkmen, 2000). The bacterium displays lipolytic activity also under refrigeration temperature (Nowak et al., 2012) in prepacked and vacuum packed meat products (Gardner, 1981) which helps bacteria to grow under $\mathrm{O}_{2}$ depletion and in presence of $\mathrm{CO}_{2}$ concentrations (Pin et al., 2002). B. thermosphacta produces volatile compounds such as acetoin, diacetyl (aerobic growth), or lactic acid and ethanol (anaerobic growth) causing flavor deterioration and strong off-odors in meat (Borch et al., 1996; Stanley, 1981; McLean and Sulzbacher, 1953). These characteristics reveal why B. thermosphacta is a significant 
55 Atmospheric pressure cold plasma (ACP) has proven potential for the microbial decontamination of fresh produce such as lettuce, tomatoes and strawberries (Ziuzina et al., 2015; Misra et al., 2014; Ziuzina et al., 2014) as well as almonds, seeds and spices (Ling et al., 2015; Kim et al., 2014; Niemira et al., 2014). Thus ACP has potential for control of meat surface and meat processing surface contaminants and investigating the susceptibility of key spoilage micro-organisms such as $B$. thermosphacta is necessary to develop applications. Cold plasma comprises of a partially ionized gas which consists of electrons, ions (positive \& negatives ions) and also neutral species including molecules in excited and non-excited state (Misra et al., 2011; Bazaka et al., 2011). Several physical and chemical reactive species involved in bacterial inactivation are generated within cold plasma; these species include reactive oxygen species (ROS), reactive nitrogen species (RNS), ultraviolet radiation (UV) and charged particles (Gaunt et al., 2006). Identified ROS involved include ozone, singlet oxygen, nitric oxide, hydroxyl radicals, hydrogen peroxide, and superoxides (Fridman, 2008). These have cellular interactions at the bacterial cell wall and membrane thus causing damage to proteins, nucleic acids and surface cell lesions (Han et al., 2015; Green et al., 2012; Laroussi et al., 2003).

This study examines the potential control of $B$. thermosphacta as a key spoilage microorganism of fresh meat using high voltage ACP. Planktonic as well as biofilm challenges prepared on abiotic and meat surfaces were exposed to plasma reactive species to evaluate the potential efficacy against the likely modes of contamination in meat and processing plants. In-package treatment provides the dual advantages of mitigating against recontamination or cross contamination events within processing and compatibility with the widely applied meat preservation technology of modified or controlled atmosphere packaging. Thus, this study investigated interactions of plasma discharging in modified atmosphere packaged (MAP) meat samples to ascertain if this provides a processing advantage for microbial reduction and 
control. Evaluation of the potential for resistance or domination of some microflora as a result of ACP treatment was explored using community profiling as a pre-requisite for the safety of adopting this technology within a meat processing environment.

\section{Material and methods}

\subsection{Inoculum preparation}

B. thermosphacta ATCC 11509 was obtained in form of lyophilized culture from Microbiologics ${ }^{\circledR}$ and was stored at $4^{\circ} \mathrm{C}$. Cells were maintained in $87 \%$ glycerol at $-80^{\circ} \mathrm{C}$ and propagated as the working culture on Tryptic soy agar (TSA, Scharlau Chemie, Barcelona, Spain) supplemented with $0.01 \mathrm{M} \mathrm{CaCl}_{2}$ at $26^{\circ} \mathrm{C}$ for $48 \mathrm{~h}$ before storage at $4^{\circ} \mathrm{C}$.

Working culture (planktonic bacterial cell suspension) was propagated overnight in $12 \%$ Beef Extract broth (BE, Scharlau Chemie, Barcelona, Spain) at $26^{\circ} \mathrm{C}$ for $18 \mathrm{~h}$. Cells were then centrifuged at 10,000 rpm for $10 \mathrm{~min}$ and the cell pellet was washed and re-suspended in 10 $\mathrm{ml}$ of phosphate buffer solution (PBS, Oxoid LTD, UK). The final bacterial cell density was adjusted to $10^{7-8} \mathrm{CFU} \mathrm{ml}^{-1}$ in $\mathrm{PBS}, 3 \%$ or $12 \% \mathrm{BE}$.

For biofilm formation, the bacterial suspension $(200 \mu \mathrm{l})$ at a concentration of $1.0 \times 10^{7-8} \mathrm{CFU}$ $\mathrm{ml}^{-1}$ was dispensed into each well of a micro-titre plate. BE broth without inoculum was the negative control. After every $24 \mathrm{~h}$ of incubation, the supernatant (with non-adherent cells) was replaced with fresh broth and further incubated for $24 \mathrm{~h}$ at $26^{\circ} \mathrm{C}$. The supernatant was then carefully aspirated and wells were rinsed thrice with PBS to remove non-adherent cells. Prior to each experiment the biofilm grown on micro-titre plate was air dried for $60 \mathrm{~min}$. The biofilm growth and density was monitored in a 96 well micro-titre plate using the Crystal violet $(\mathrm{CV})$ assay. The antibacterial effect of applied ACP treatment on bacterial biofilm was quantified using Plate count (PC) method. 


\subsection{DIT-120 plasma device/system}

A custom built large gap dielectric barrier discharge (DBD) system (DIT-120) was used (Figure 1). DIT-120 consists of high voltage transformer with maximum voltage output of $120 \mathrm{kV}$ at $50 \mathrm{~Hz}$. The system is further described in Han et al. (2015). The distance between the two electrodes was maintained at $30 \mathrm{~mm}$ for liquid studies and $45 \mathrm{~mm}$ for meat studies, which was depending on the height of the container used.

\subsection{In package Plasma treatment of Liquids}

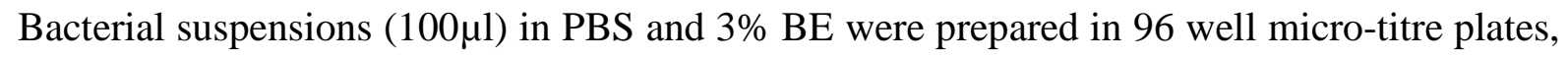
placed at the center of the polypropylene plastic container and then sealed in a high barrier polypropylene bag (Cryovac, B2630, USA). The samples were placed at the center of the electrodes of the system, and exposed to a voltage range of $60-80 \mathrm{kV}_{\mathrm{RMS}}$ in conjunction with treatment times from 15-300s using air as the inducer gas. The effect of post treatment storage time was evaluated; samples were stored for $1 \mathrm{~h}$ or $24 \mathrm{~h}$ at $26^{\circ} \mathrm{C}$ or $4^{\circ} \mathrm{C}$ post plasma treatment. Experiments were performed in duplicate and replicated twice. A bacterial suspension without any plasma treatment was kept as a negative control and stored under similar conditions throughout the study.

\subsection{In package Plasma treatment of biofilms}

Brochothrix biofilms grown for $48 \mathrm{~h}$ on micro-titre plate were ACP treated at $80 \mathrm{kV}$ for 60 , 120 or $300 \mathrm{~s}$, using air as the inducer gas. Samples were subjected to post treatment storage for $24 \mathrm{~h}$ and efficacy was evaluated using plate count and XTT assay.

\subsection{Raw Meat Challenge study}

Bacteria were cultivated using $12 \%$ beef extract broth and incubated overnight. Overnight culture was centrifuged at 10,000 rpm for 10 min and the cell pellet was washed thrice with 
$12610 \mathrm{ml}$ of sterile PBS. The pellet was re-suspended in sterile PBS and bacterial density was 127 adjusted to $10^{7-8} \mathrm{CFU} \mathrm{ml}^{-1}$.

128 Samples of lamb chops were purchased from a local retailer, Dublin, Ireland. Approximately $12925 \mathrm{~g}$ of lamb was spot inoculated with $1 \mathrm{ml}$ of prepared bacterial suspension. The inoculated samples were allowed to dry to facilitate surface attachment of the bacteria. Samples were then placed inside a plastic tray (196 x154 mm and $45 \mathrm{~mm}$ depth), flushed with $30 \% \mathrm{CO}_{2}+$ $70 \% \mathrm{O}_{2}$ modified atmosphere gas mixture using the vacuum packaging machine (Lavezzini VG600, UK) and sealed prior to treatment.

For the microbiological analysis, inoculated untreated samples were prepared to determine the initial sessile bacterial challenge following attachment; Inoculated treated samples to assess efficacy of the ACP treatment, un-inoculated untreated samples to estimate the initial micro-flora and un-inoculated treated samples to analyze effect of ACP treatment on the background micro-flora, respectively. The prepared lamb samples were treated at $80 \mathrm{kV}$ for 1 min. The lamb samples were stored at $4^{\circ} \mathrm{C}$ for predetermined interval days: $0,1,4,7,10$, and 13 (to evaluate the potential for shelf-life extension). All experiments were carried out in duplicate and replicated twice.

\subsection{Concentration of reactive species inside packages}

143 Ozone and carbon monoxide concentrations were measured inside the sealed packages containing the Lamb sample using Gastec ozone and carbon monoxide detection tubes (Gastec Corporation, Japan). Measurements were taken immediately after plasma treatment, after 1 hour and 24 hours of post-treatment storage.

\subsection{Microbiological analysis}

148 Plasma treated samples (either PBS or 3\% BE) were serially diluted in sterile Maximum 149 Recovery Diluent (MRD) and $1 \mathrm{ml}$ and $0.1 \mathrm{ml}$ aliquot of appropriate dilutions were surface 
plated on TSA $+0.01 \mathrm{M} \mathrm{CaCl}_{2}$ plates. The plates were incubated aerobically at $26^{\circ} \mathrm{C}$ for $24 \mathrm{~h}$ and for a further $24 \mathrm{~h}$ to observe any subsequent increase in visible colonies.

152 The bacterial biofilm formation capacity was monitiored using crystal violet assay as described in Stepanovi'c et al. (2000) after 24, 48h and 72h incubation times. The absorbance was measured at 590nm using a micro-titre plate reader (Synergy HT, Biotek Instruments Inc.). Each biofilm well absorbance value was corrected by subtracting the means of absorbance of a blank (un-inoculated) beef extract.

Following each ACP treatment and 24h post treatment storage, the bacterial biofilm in 96 well plate was re-suspended in $200 \mu$ l of sterile PBS. In order to disrupt the adhered biofilm, the plate was sonicated (Bransonic 5510E-MT, US) for 5min. The suspension was then pooled in sterile microtubes and serially diluted in sterile MRD which was further plated on TSA $+0.01 \mathrm{M} \mathrm{CaCl}_{2}$. The plates were incubated at $26^{\circ} \mathrm{C}$ for $24 \mathrm{~h}$ to $48 \mathrm{~h}$. Results obtained represented the survival bacterial population in $\log _{10} \mathrm{CFU} \mathrm{ml}{ }^{-1}$. The plates with no growth were further incubated until $72 \mathrm{~h}$ and checked for the presence of colonies every $24 \mathrm{~h}$.

The effect of the ACP treatment on biofilm metabolic activity was determined using XTT assay after each ACP treatment and $24 \mathrm{~h}$ post treatment storage to evaluate post treatment population viability. Fresh XTT stock solution was prepared as described in Peeters et al.

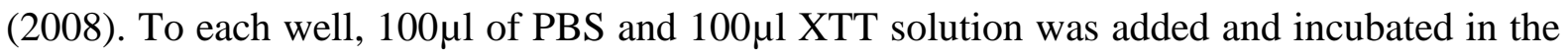
dark for $5 \mathrm{~h}$ at $37^{\circ} \mathrm{C}$. After incubation, the supernatant from each well $(100 \mu \mathrm{l})$ was transferred into a new micro-titre plate and absorbance was recorded at $486 \mathrm{~nm}$ using a micro-titre plate

170 reader (Synergy HT, Biotek Instruments Inc.). The percentage of surviving bacterial population was calculated by comparing the absorbance of the treated samples with the absorbance of the negative control (TSB without inocula) and untreated control biofilms, respectively. 
174 To quantify effects on lamb, approximately $10 \mathrm{~g}$ of lamb was sampled using a sterile forceps and scalpel, transferred to a stomacher bag (BA6041, Seward LTD, UK) with the addition of $10 \mathrm{ml}$ of sterile Maximum recovery diluent (MRD) and stomached for $2 \mathrm{~min}$. Subsequent decimal dilutions were made in MRD and were surface plated on selective media STAA agar (streptomycin-sulphate, thallous-acetate and actidione, Oxoid CM881) with STA selective supplement (Oxoid SR0151). Surviving background microflora (aerobic mesophilic bacteria) isolated from raw lamb was evaluated using non-selective TSA media incubated aerobically at $26^{\circ} \mathrm{C}$ for $24-48 \mathrm{~h}$. Replicate samples were obtained from each tray to ensure reproducibility of the experimental data and all experiments were performed in duplicate. Results are reported as $\log 10 \mathrm{CFU} / \mathrm{g}$ with error bars representing standard deviation.

\subsection{Community profiling}

Bacterial community profiling was performed on the same meat samples which were used for the shelf-life study. To this end, homogenized samples, which were used for determination of the background microflora using plate count assays, were frozen at $-20^{\circ} \mathrm{C}$ until further use. The procedure for isolation of bacterial DNA from meat samples was optimized from methods used by Hu et al. (2009) and the instructions supplied with the Promega Wizard® genomic DNA isolation kit (Promega) to increase the recovery of bacterial DNA. In brief, $10 \mathrm{~g}$ meat samples were stomached with $10 \mathrm{ml}$ MRD for $10 \mathrm{~min}$. The homogenate was transferred to a $25 \mathrm{~mL}$ tube and filled to the top with MRD. Samples were spun at $400 \mathrm{~g}$ for $10 \mathrm{~min}$ and the supernatant was transferred to a fresh tube and spun at $10000 \mathrm{~g}$ for $20 \mathrm{~min}$. The pellet was resuspended in $480 \mu \mathrm{L}$ of $50 \mathrm{mM}$ EDTA, transferred to an Eppendorf tube and $120 \mu \mathrm{L}$ of lysozyme/lysostaphin ( $5 \mu \mathrm{g} / \mathrm{mL}$ lysozyme, $0.1 \mu \mathrm{g} / \mathrm{mL}$ lysostaphin) were added and samples incubated at $37{ }^{\circ} \mathrm{C}$ for 1 hour. DNA isolation was then performed as per manufacturers' instructions. The recovery of DNA was confirmed using agarose gel electrophoresis and visualization with ethidium bromide. Gels contained 1\% agarose in TAE 
or TBE buffer and electrophoresis was performed at $120 \mathrm{~V}$ for $30 \mathrm{~min}$ followed by visualization using UV transillumination on the AlphaImager system (Alpha Innotech).

\section{PCR amplification}

202

The V3 region of the 16S rRNA gene with a size of approximately 230 basepairs (bp) was amplified using the gc338f (5' CGC CCG CCG CGC GCG GCG GGC GGG GCG GGG GCA CGG GGG GAC TCC TAC GGG AGG CAG CAG-3') and 518r (5' ATT ACC GCG GCT GCT GG 3') primer set. The reaction mixture contained $8.5 \mu \mathrm{L}$ water, $12.5 \mu \mathrm{L}$ GoTaq Green MasterMix (Promega), $1 \mu \mathrm{L}$ of primer $1(10 \mu \mathrm{M}), 1 \mu \mathrm{L}$ of primer $2(10 \mu \mathrm{M})$ and $2 \mu \mathrm{L}$ of total DNA, in a total reaction volume of $25 \mu \mathrm{L}$. PCR amplification was performed using a touchdown programme on the G-Storm thermocycler in which the temperature was decreased from $65{ }^{\circ} \mathrm{C}$ to $55^{\circ} \mathrm{C}$ in 5 cycles, followed by 25 cycles at $55^{\circ} \mathrm{C}$, and final elongation at $72{ }^{\circ} \mathrm{C}$ for $10 \mathrm{~min}$. To confirm successful amplification, $5-10 \mu \mathrm{L}$ of the reaction mixture were run on a $1.2 \%$ agarose gel, followed by visualization with ethidium bromide. DNA extracted from meat samples was used as template as well as DNA extracted from pure over-night cultures of E. coli, S. aureus, L. monocytogenes, C. jejuni, and B. thermosphacta.

\section{DGGE}

The 230 bp PCR products were separated by denaturing gradient gel electrophoresis using the CBS DGGE 4001 system (CBS Scientific, CA, USA). PCR products were diluted with 0.5x TAE buffer and DNA loading dye or left undiluted and 2.5-5 $\mu \mathrm{L}$ of sample were loaded onto $8 \%$ (wt/vol) polyacrylamide gels (acrylamide/bisacrylamide 37.5:1) in $0.5 x$ TAE buffer with a 30-60\% gradient of urea and formamide. Electrophoresis was performed at $60^{\circ} \mathrm{C}$ for 10 min at $200 \mathrm{~V}, 40 \mathrm{~mA}$ and then for 6 hours at $150 \mathrm{~V}$. Gels were stained with SybrGold DNA stain (Molecular Probes, Netherlands), diluted 1:10000 in 0.5x TAE buffer, for 20 min and imaged with UV transillumination with the AlphaImager (Alpha Innotech) system. 


\subsection{Statistical analysis}

Each experiment was carried out in duplicate and replicated twice to ensure reproducibility of the experimental data. Data were analyzed using SPSS 22.0 (SPSS Inc., Chicago, USA) to carry out statistical analysis. $\mathrm{P}$ values $<0.05$ were considered significant.

\section{Results}

\subsection{B. thermosphacta is susceptible to ACP}

Post treatment storage interval was found to control inactivation. The bacterial inactivation after ACP treatment with $1 \mathrm{~h}$ and $24 \mathrm{~h}$ post treatment storage time (PTST) is represented in Fig. 2. Plasma treatment of bacterial cells in PBS reduced the bacterial population by 5 Log cycles with $15 \mathrm{~s}$ of plasma treatment at $80 \mathrm{kV}$ with a $24 \mathrm{~h}$ post treatment storage period. Populations were undetectable after 30 s or 60 s treatment time. While with 1 h post treatment storage time, $30 \mathrm{~s} \mathrm{ACP}$ treatment showed \pm 1.5 Log cycles reduction. Increasing treatment time to 60s with 1 hour PTST, reduced populations to undetectable levels. The limit of detection was $1 \log _{10} \mathrm{CFU} \mathrm{ml} \mathrm{m}^{-1}$. Thus, various inactivation rates were observed based on different in package post treatment storage time intervals.

Increasing the voltage level was found to enhance the inactivation rates. Previous studies have shown the dependency of microbial inactivation on the voltage level (Han et al., 2014). The interaction of voltage level and post treatment storage interval were further investigated here for B. thermosphacta (Table 1). With $24 \mathrm{~h}$ post treatment storage, ACP treatment at $60 \mathrm{kV} \& 70 \mathrm{kV}$ for $15 \mathrm{~s}$ showed reduction of $\sim 2-3 \mathrm{Log}$ CFU ml ${ }^{-1}$. Maximum reduction of $5 \mathrm{log}$ cycles was observed with $15 \mathrm{~s}$ of ACP treatment at $80 \mathrm{kV}$. While with $1 \mathrm{~h}$ storage, a lower reductions of $1.5 \pm 0.5 \log _{10} \mathrm{CFU} \mathrm{ml} \mathrm{m}^{-1}$ was observed even with extending the treatment time to 30 seconds at $70 \mathrm{kV}$ and $80 \mathrm{kV}$. The bacterial population was undetectable after $60 \mathrm{~s}$ of treatment with all storage time and voltage levels except $60 \mathrm{kV}$ voltage treatment with $1 \mathrm{~h}$ post 
treatment storage. However, the effect of ACP was clearly observed after 300s of treatment.

249 Greater inactivation was observed with increasing voltage and post treatment storage time.

\subsection{A nutritive environment offers protection against inactivation by ACP}

251

252

253

254

255

256

257

The inactivation of $B$. thermosphacta was investigated in meat model medium (Fig. 3, Table

2). Plasma treatment was performed in a liquid meat model which was composed of $3 \%$ beef extract. Samples were treated with direct plasma discharge at $80 \mathrm{kV}$ with $24 \mathrm{~h}$ post treatment storage period at $26^{\circ} \mathrm{C}$. Table 2 shows that $B$. thermosphacta grown in the meat model present a greater challenge to ACP inactivation than in PBS. The bacterial population was reduced by $2.5 \pm 0.1 \log _{10} \mathrm{CFU} \mathrm{ml}{ }^{-1}$ in beef extract after 300 s of treatment while complete inactivation in PBS was achieved after 30s. A protective effect against ACP treatment was observed with the high nutrient content meat model (3\% beef extract).

\subsection{Adhesion and Biofilm formation capacity of B. thermosphacta}

A preliminary adhesive assay was performed to evaluate the ability of $B$. thermosphacta to adhere to polystyrene surface plates and also to study the conditions at which the bacteria were able to form a biofilm. Bacteria were grown in $3 \%$ and $12 \%$ model meat media at different growth durations. B. thermosphacta displayed adhesive behavior and biofilms developed with increasing nutrient content and incubation periods (Fig.4). All in vitro assays, i.e. OD measurement at 590nm, CV assay and PCA assay showed similar growth kinetics of B. thermosphacta biofilms. These findings reflect the bacteria's ability to generate additional biofilm biomass in nutrient rich environmental conditions.

\subsubsection{Biofilm monitoring by Crystal violet (CV) assay}

The results demonstrated low biofilm formation after $24 \mathrm{~h}$ of incubation while the biofilm forming capacity was increased up to $48 \mathrm{~h}$ (Fig. 4), therefore the $48 \mathrm{~h}$ incubation period was selected for further investigations. 
B. thermosphacta was grown in $0.5 \%, 1.2 \%, 3 \%$ and $12 \%$ beef extract medium. Bacteria grown on $12 \%$ beef extract showed the highest biofilm formation, which was confirmed by standard plate count method. Decrease in biofilm formation was observed with a decrease in nutrient composition of the beef extract. There was no statistical difference in biofilm formation observed for bacteria grown in $1.2 \%$ and $0.5 \%$ beef extract broth (Fig. 5). No biofilm was detected in the negative control wells which only contained culture media.

\subsection{ACP treatment interactions within biofilm in nutritive environment}

In order to study the efficiency of ACP to inactivate $B$. thermosphacta biofilm, the $48 \mathrm{~h}$ bacterial biofilm grown in $12 \% \mathrm{BE}$ was treated at high voltage of $80 \mathrm{kV}$ for $60 \mathrm{~s}, 120 \mathrm{~s}$ and 300s of treatment time. Surviving populations were estimated using viable cell counts (Fig. 6) and residual metabolic activity using XTT assay (Fig. 7).

Biofilm population of $B$. thermosphacta was significantly reduced $(p \leq 0.05)$ from $\log 8$ $\mathrm{CFU} \mathrm{ml}{ }^{-1}$ to $4 \pm 0.6 \mathrm{Log} \mathrm{CFU} \mathrm{ml}{ }^{-1}$ after 60 s of ACP treatment. Prolonging the ACP treatment time to $120 \mathrm{~s}$ further reduced populations to $3 \pm 0.1 \mathrm{Log} \mathrm{CFU} \mathrm{m}{ }^{-1}$; however, there was no further significant effect of extending treatment to 300s (Fig. 6).

XTT assay was carried out immediately post ACP treatment and 24h PTST (Fig. 7). The ACP treatment of $80 \mathrm{kV}$ for $60 \mathrm{~s}$ and 120 s reduced the bacterial metabolic activity by $35 \%$ and $52 \%$ respectively. However, no further reductions were observed after prolonging the treatment time to 300 s, indicating a significant retention of metabolic activity.

\subsection{Effects of in package ACP treatment of lamb chop}

Initial background microflora levels present on raw lamb chop and its reduction by ACP treatment is shown in Figure 8. The average initial concentration of background micro-flora on the lamb sample was approximately $6 \log _{10} \mathrm{CFU} / \mathrm{g}$, with no significant reduction of bacterial loads observed immediately post treatment. However, between days 7 and 10 of 
storage, bacterial concentrations in plasma treated samples were about $1 \log _{10} \mathrm{CFU} / \mathrm{g}$ lower than those of untreated controls, indicating a reduced microbial growth rate. A total viable count of approx. $10^{7} \mathrm{CFU} / \mathrm{g}$ was recorded at the end of the shelf-life study on day 13 , a concentration considered in the range of borderline acceptable for MAP packed meats according to the UK Health Protection Agency (HPA, 2009). It is reported as the general threshold value for spoilage causing sensorial deterioration, such as off-odors and slime (Degirmencioglu et al., 2012, Limbo et al., 2010, Koutsoumanis et al., 2008; Rao and Sachindra, 2002).

Further, the response of $B$. thermosphacta inoculated on lamb to in-package treatment was investigated. Inoculated samples were MAP packaged under high oxygen content (70\%) and then treated with ACP for $1 \mathrm{~min}$ at $80 \mathrm{kV}$. The average initial population of challenge bacteria attached on the meat was approximately $6 \mathrm{Log} \mathrm{CFU} / \mathrm{g}$, which showed a significant $0.8 \mathrm{Log}$ $\mathrm{CFU} \mathrm{ml} \mathrm{m}^{-1}$ reduction immediately post treatment $(\mathrm{p}<0.05)$. Gradually the bacteria recovered during the storage period and an increase in bacterial concentration was observed over the following 24h (Fig. 9a). A difference of $\log _{10} 0.2-0.4 \mathrm{CFU} \mathrm{ml}{ }^{-1}$ was maintained between the control and the treated samples up to the end of the storage time ( $\mathrm{p}<0.05$ on day 0,4 and 7 ). As demonstrated by enumeration on STAA selective agar plates, B. thermosphacta subjected to ACP treatment showed an initial reduction of $1 \log _{10} \mathrm{CFU} \mathrm{m}{ }^{-1}$, however with longer storage periods the remaining bacterial population did grow to levels similar to untreated samples (Fig 9b).

Both ozone and carbon monoxide concentration were measured inside the trays immediately after treatment and after post-treatment storage (Table 3). High ozone concentrations were detected for lamb which could be attributed to the in-package headspace, thus trapping more reactive species in the package. Carbon monoxide $(\mathrm{CO})$ is one of the main concerns of the meat industry due to its high toxicity and for being a meat colorant currently banned in the 
321 EU as it stabilizes the red color and may mask visual evidence of spoilage. CO was undetectable after treatment at $80 \mathrm{kV}$ for 1 minute, suggesting that plasma treatment of meat packaged under a modified atmosphere of $30 \% \mathrm{CO}_{2}+70 \% \mathrm{O}_{2}$ gas mixture does not result in carbon monoxide concerns with none detected immediately after treatment or indeed after 1 hour post treatment sealed storage. The meat volume and tray size appeared to have an important influence on the ozone generation, being large portions of meat and trays exceeding the electrode dimensions where ozone was generated in lower amounts. Further, carbon monoxide was not detected in lamb trays therefore toxicity concerns related to the potential high concentrations of carbon monoxide generated during the plasma treatment can be discarded.

\subsection{Community profiling demonstrates microbiological safety of ACP treatment}

For community profiles of lamb samples, sampling points at days 7 and 14 in particular, showed 5 strong bands, showing the predominance of 5 different microbial species at this point (Figure 10). Amplicons of the bacterial species E. coli, L. monocytogenes, S. aureus, C. jejuni and B. thermosphacta, which present potential challenge microorganisms for meat products, were used as standards for method optimisation and comparison. Importantly, no striking differences in population diversities were observed between plasma treated and control samples. No predominant species absent in the control samples later emerged in treated samples, which could have suggested a stronger resistance of particular species to plasma exposure. Furthermore, comparison with the bands of known bacterial standards, suggests $B$. thermosphacta (lane 14) as a predominant species in the control samples, whereas the pathogenic micro-organisms were not identified in the control lamb samples. Microbial diversity increased over storage time. 


\section{Discussion}

B. thermosphacta is a predominant feature of raw meat products (Osés et al., 2013; Borch et al., 1996) and is known to cause significant meat spoilage (Ercolini et al., 2006). Atmospheric Cold Plasma as a novel technology can be designed for flexibility in application point and therefore may be incorporated into food or food environment decontamination systems, but requires risk specific evaluation. Therefore in this study we examined the susceptibility of $B$. thermosphacta to ACP treatment, taking microbial and food environment challenges into consideration, in response to system and process parameters. Preliminary studies demonstrated applied voltage level and treatment time along with PTST played a critical role in the rate of ACP inactivation against planktonic cells of $B$. thermosphacta. Higher inactivation efficiency of ACP against planktonic cells was observed with increasing applied voltage levels and treatment time. An elevation in the concentration of the reactive species (like ROS and RNS) has been reported with increasing voltage levels in association with a higher bactericidal effect (Han et al., 2016, Cullen et al., 2013). These reactive species generated are known to play an important role in bacterial inactivation, they have the ability to disrupt the bacterial cell and destroy macromolecules like DNA, proteins and lipids thus resulting in bacterial inactivation (Han et al., 2014). In our study, 60kV of ACP treatment of bacteria suspended in PBS showed slow bacterial reduction but prolonging the treatment time to $60 \mathrm{~s}$ lead to inactivation below detection. At $80 \mathrm{kV}$ of ACP treatment, the effects were apparent with 30s treatment time yielding inactivation below detection limits. Similar trends were observed in relation to applied voltage and treatment time by Han et al. (2014) and Niemira et al. (2014). A range of post treatment storage conditions were evaluated, where 24h of PTST was found to be most compatible for further experiments as it allowed longer interaction between the bacteria and the reactive species thus retaining efficacy against the target. 
B. thermosphacta biofilm growth was strong with aggregated biofilm mass apparent in the nutrient rich conditions. This was greatly dependent on $\%$ medium, with high biofilm formation in $12 \%$ beef extract. These results are in agreement with other studies by Zeraik \& Nitschke (2012) and Stepanovic et al. (2004) demonstrating strong influence of nutritional availability on the surface properties of bacteria and biofilm formation. A strong bactericidal effect in the biofilm was observed with increasing plasma treatment time from 60 to 300s. However, significant metabolic activity was retained as observed by XTT assay, and complete bacterial inactivation was not achieved even after 300s of ACP treatment, indicating a viable but non-culturable state. B. thermosphacta biofilms grown in $12 \%$ beef extract were found to be more resistant to plasma treatment compared to planktonic cells. According to previous studies by Han et al. (2014), Ulbin-Figlewicz et al. (2014), Lee et al. (2006), Gram positive bacteria were shown to be more resistant to ACP treatment than Gram negative bacteria. The composition and thickness of the biofilm structure varies with type and strain of bacteria which significantly affects the rate of ACP inactivation. Therefore, further study is warranted to elucidate if ACP could mitigate B. thermosphacta biofilm formation, either on biotic or abiotic surfaces.

The media employed also had a strong influence over the ACP bacterial inactivation, showing a significant difference in the rate of bacterial inactivation when treated in PBS and model meat media. Liquid inactivation studies in meat model media showed minimum reduction of $\pm 2.5 \mathrm{Log} \mathrm{CFU} \mathrm{m}{ }^{-1}$ after 300 s of ACP treatment, while \pm 1 Log CFU ml ${ }^{-1}$ bacterial reduction were obtained in lamb samples. The growth and survival of $B$. thermosphacta in model meat media and lamb may be attributed to the high nutrient conditions, complexity of the meat matrix and ability of the bacteria to grow in varied conditions. Previous studies by Williams et al. (2005) have reported that the presence of high organic components in the medium had certain protective effect against the bactericidal 
effects of plasma. Plasma treatment generates several reactive species which include atomic oxygen, metastable singlet state oxygen, ozone, hydrogen peroxide etc. These organic components in the media are scavengers for reactive species, which oxidize these higher organic components breaking them into intermediate products (Reszka et al., 2010) and thus protecting the bacterial cells from death (Patil et al., 2009). It can also be noted that (i) the initial concentration of the challenge bacteria inoculated or present as background on meat sample was higher than generally found on meat in industry, (ii) the time-lapse between slaughter and MAP packaging as meat were purchased from local retail shop may have further contributed to early meat spoilage. Further, the microbial community profiling of lamb samples showed no evident changes or emergence of predominant species after the treatments during the shelf-life study. The results obtained suggest that plasma treatment in conjunction with MAP does not introduce a theoretical risk with regards to allowing some populations to predominate and does not positively select certain bacterial species. The diversity of reactive species generated with ACP and the complexity of their mechanisms of action mitigates against microbial resistance to ACP, but this should be confirmed for key risks. Thus, the overall results reported here indicate that ACP has good potential to be an alternative safe decontamination process in meat industry, whether for raw meat product or the related processing environment. The demonstrated challenge associated with effecting control on highly nutritive surfaces, informs the need for flexibility in ACP treatment application particularly to foods themselves, where repetitive or pulsed treatment may offer advantages over single stage interventions. The simultaneous evaluation of the wide range of parameters reported here provides broad insights into decontamination or control of a major spoilage bacteria namely; B. thermosphacta, using ACP technology which can facilitate the further scale-up and optimization. 


\section{Conclusions}

419 In conclusion, ACP was found to be effective against planktonic cells of Brochothrix 420 thermosphacta, providing complete inactivation in PBS and effectively reducing the bacterial 421 load in meat model media and on lamb both as planktonic and biofilm cells. The results 422 obtained showed significant influence of system and treatment parameters on the rate of 423 bacterial inactivation. Overall, the results show potential of high voltage in-package 424 atmospheric cold plasma treatment in reducing spoilage bacteria like $B$. thermosphacta on 425 meat products and meat environments, although process intensification is required for 426 complete elimination of $B$. thermosphacta by ACP. This treatment method could not only 427 help inhibit the population of spoilage bacteria but also ensure microbial safety by prolonging 428 the shelf life of meat while maintaining food quality.

\section{Acknowledgment}

430 The research leading to these results has received funding from the European Community's 431 Seventh Framework Program (FP7/2207-2013) under grant agreement number 285820. 


\section{References}

Adams, M.R., Moss, M.O., 2000. Food Microbiology, Food Microbiology.

Bazaka, K., Jacob, M. V, Crawford, R.J., Ivanova, E.P., 2011. Plasma-assisted surface modification of organic biopolymers to prevent bacterial attachment. Acta Biomater. 7, 2015-28. doi:10.1016/j.actbio.2010.12.024

Borch, E., Kant-Muermans, M.-L., Blixt, Y., 1996. Bacterial spoilage of meat and cured meat products. Int. J. Food Microbiol. 33, 103-120. doi:10.1016/0168-1605(96)01135-X

Collins-Thompson, D.L., Rodriguez Lopez, G., 1980. Influence of sodium nitrite, temperature, and lactic acid bacteria on the growth of Brochothrix thermosphacta under anaerobic conditions. Can. J. Microbiol. 26, 1416-1421.

Cullen, P., Pankaj, S., Misra, N., Pankaj, S.K., Misra, N.N., Cullen, P.J., 2013. Kinetics of Tomato Peroxidase Inactivation by Atmospheric Pressure Cold Plasma Based on Dielectric Barrier Discharge. Innov. Food Sci. Emerg. Technol. 19, 153-157.

Degirmencioglu, N., Esmer, O.K., Irkin, R., Degirmencioglu, A., 2012. Effects of Vacuum and Modified Atmosphere Packaging on Shelf Life Extention of Minced Meat Chemical and Microbiological Changes. J. Anim. Vet. Adv. 11, 898-911. doi:10.3923/javaa.2012.898.911

Dobrynin, D., Fridman, G., Friedman, G., Fridman, A., 2009. Physical and biological mechanisms of direct plasma interaction with living tissue. New J. Phys. 11, 115020. doi:10.1088/1367-2630/11/11/115020

Ercolini, D., Russo, F., Torrieri, E., Masi, P., Villani, F., 2006. Changes in the SpoilageRelated Microbiota of Beef during Refrigerated Storage under Different Packaging Conditions. Appl. Environ. Microbiol. 72, 4663-4671. doi:10.1128/AEM.00468-06

Erkmen, O., 2000. Antimicrobial effects of pressurised carbon dioxide on Brochothrix thermosphacta in broth and foods. J. Sci. Food Agric. 80, 1365-1370. doi:10.1002/1097-0010(200007)80:9<1365::AID-JSFA652>3.0.CO;2-P

Fridman, A., 2008. Plasma chemistry. Cambridge university press.

Fridman, G., Brooks, A.D., Balasubramanian, M., Fridman, A., Gutsol, A., Vasilets, V.N., Ayan, H., Friedman, G., 2007. Comparison of Direct and Indirect Effects of NonThermal Atmospheric-Pressure Plasma on Bacteria. Plasma Process. Polym. 4, 370-375. doi:10.1002/ppap.200600217

Gardner, G.A., 1981. Brochothrix thermosphacta (Microbacterium thermosphactum) in the spoilage of meat: a review, in: Roberts, T.A., Hobbs, G., Christian, J.H.B. and Skovgaard, N. (Eds.), Psychrotrophic Microorganisms in Spoilage and Pathogenicity. Academic Press, Great Britain, pp. 139-175.

Gaunt, L.F., Beggs, C.B., Georghiou, G.E., 2006. Bactericidal Action of the Reactive Species Produced by Gas-Discharge Nonthermal Plasma at Atmospheric Pressure: A Review. IEEE Trans. Plasma Sci. 34, 1257-1269. doi:10.1109/TPS.2006.878381 
Green, A. K., Guzel-Seydim, Z. B. and Seydim, A.C., 2012. Chemical and physical properties of ozone, in: O'Donnel, C., Tiwary, B. K., Cullen, P. J. and Rice, R. G. (Eds.), Ozone in Food Processing. Blackwell Publishing Ltd, UK, pp. 26-28.

Gribble, A., Brightwell, G., 2013. Spoilage characteristics of Brochothrix thermosphacta and campestris in chilled vacuum packaged lamb, and their detection and identification by real time PCR. Meat Sci. 94, 361-368. doi:http://dx.doi.org/10.1016/j.meatsci.2013.03.016

Han, L., Patil, S., Boehm, D., Milosavljević, V., Cullen, P.J., Bourke, P., 2016. Mechanisms of Inactivation by High-Voltage Atmospheric Cold Plasma Differ for Escherichia coli and Staphylococcus aureus. Appl. Environ. Microbiol. 82, 450-458. doi:10.1128/AEM.02660-15

Han, L., Patil, S., Keener, K.M., Cullen, P., Bourke, P., 2014. Bacterial Inactivation by High Voltage Atmospheric Cold Plasma: Influence of Process Parameters and Effects on Cell Leakage and DNA. J. Appl. Microbiol. doi:10.1111/jam.12426

Hu, P., Zhou, G., Xu, X., Li, C., Han, Y. Characterization of the predominant spoilage bacteria in sliced vacuum-packed cooked ham based on 16S rDNA-DGGE, Food Control, Volume 20, Issue 2, February 2009, Pages 99-104, ISSN 09567135, http://dx.doi.org/10.1016/j.foodcont.2008.02.007.

Kim, J.E., Lee, D.-U., Min, S.C., 2014. Microbial decontamination of red pepper powder by cold plasma. Food Microbiol. 38, 128-36. doi:10.1016/j.fm.2013.08.019

Koutsoumanis, K.P., Stamatiou, A.P., Drosinos, E.H., Nychas, G.-J.E., 2008. Control of spoilage microorganisms in minced pork by a self-developed modified atmosphere induced by the respiratory activity of meat microflora. Food Microbiol. 25, 915-21. doi:10.1016/j.fm.2008.05.006

Laroussi, M., Mendis, D.A., Rosenberg, M., 2003. Plasma Interaction With Microbes. New J. Phys. 5. doi:10.1088/

Lee, K., Paek, K., Ju, W.-T., Lee, Y., 2006. Sterilization of bacteria, yeast, and bacterial endospores by atmospheric-pressure cold plasma using helium and oxygen. J. Microbiol. 44, 269-75.

Limbo, S., Torri, L., Sinelli, N., Franzetti, L., Casiraghi, E., 2010. Evaluation and predictive modeling of shelf life of minced beef stored in high-oxygen modified atmosphere packaging at different temperatures. Meat Sci. 84, 129-136. doi:10.1016/j.meatsci.2009.08.035

Ling, L., Jiangang, L., Minchong, S., Chunlei, Z., Yuanhua, D., 2015. Cold plasma treatment enhances oilseed rape seed germination under drought stress. Sci. Rep. 5, 13033. doi:10.1038/srep13033

Lu, H., Patil, S., Keener, K.M., Cullen, P.J., Bourke, P., 2014. Bacterial inactivation by highvoltage atmospheric cold plasma: influence of process parameters and effects on cell leakage and DNA. J. Appl. Microbiol. 116, 784-794. doi:10.1111/jam.12426

McLean, R.A., Sulzbacher, W.L., 1953. Microbacterium thermosphactum, spec: nov.; a nonheat resistant bacterium from fresh pork sausage. J. Bacteriol. 65, 428-33. 
Misra, N., Tiwari, B., Rahavarao, K., Cullen, P. 2011. Nonthermal Plasma Inactivation of Food-Borne Pathogens. Food Eng. Rev. 3, 3-4.

Misra, N.N., Han, L., Tiwari, B.K., Bourke, P., Cullen, P.J., 2014. Nonthermal plasma technology for decontamination of foods. Nov. Food Preserv. Microb. Assess. Tech. 155.

Niemira, B.A., Boyd, G., Sites, J., 2014. Cold Plasma Rapid Decontamination of Food Contact Surfaces Contaminated with Salmonella Biofilms. J. Food Sci. 79, M917M922. doi:10.1111/1750-3841.12379

Nowak, A., Rygala, A., Oltuszak-Walczak, E., Walczak, P., 2012. The prevalence and some metabolic traits of Brochothrix thermosphacta in meat and meat products packaged in different ways. J. Sci. Food Agric. 92, 1304-1310. doi:10.1002/jsfa.4701

Nychas, G.J.E., Skandamis, P.N., Tassou, C.C., Koutsoumanis, K.P., 2008. Meat spoilage during distribution. Meat Sci. 78, 77-89. doi:10.1016/j.meatsci.2007.06.020

Osés, S.M., Diez, A.M., Melero, B., Luning, P.A., Jaime, I., Rovira, J., 2013. Characterization by culture-dependent and culture-independent methods of the bacterial population of suckling-lamb packaged in different atmospheres. Food Microbiol. 36, 216-222. doi:10.1016/j.fm.2013.05.005

Patil, S., Bourke, P., Frias, J.M., Tiwari, B.K., Cullen, P.J., 2009. Inactivation of Escherichia coli in orange juice using ozone. Innov. Food Sci. Emerg. Technol. 10, 551-557. doi:10.1016/j.ifset.2009.05.011

Peeters, E., Nelis, H.J., Coenye, T., 2008. Comparison of multiple methods for quantification of microbial biofilms grown in microtiter plates. J. Microbiol. Methods 72, 157-65. doi:10.1016/j.mimet.2007.11.010

Pin, C., García de Fernando, G.D., Ordóñez, J.A., 2002. Effect of modified atmosphere composition on the metabolism of glucose by Brochothrix thermosphacta. Appl. Environ. Microbiol. 68, 4441-7.

Rao, D.N., Sachindra, N.M., 2002. Modified atmosphere and vacuum packaging of meat and poultry products. http://dx.doi.org/10.1081/FRI-120016206.

Reszka, K.J., Bilski, P.J., Britigan, B.E., 2010. Quenching of singlet oxygen by pyocyanin and related phenazines. Photochem. Photobiol. 86, 742-6. doi:10.1111/j.17511097.2010.00728.x

Stanley, G., Shaw, K.J., Egan, A.F., 1981. Volatile Compounds Associated with Spoilage of Vacuum-Packaged Sliced Luncheon Meat by Brochothrix thermosphacta. Appl. Environ. Microbiol. 41, 816-8.

Stepanović, S., Cirković, I., Ranin, L., Svabić-Vlahović, M., 2004. Biofilm formation by Salmonella spp. and Listeria monocytogenes on plastic surface. Lett. Appl. Microbiol. 38, 428-32. doi:10.1111/j.1472-765X.2004.01513.x

Stepanović, S., Vuković, D., Dakić, I., Savić, B., Švabić-Vlahović, M., 2000. A modified microtiter-plate test for quantification of staphylococcal biofilm formation. J. Microbiol. Methods 40, 175-179. doi:10.1016/S0167-7012(00)00122-6 
Ulbin-Figlewicz, N., Jarmoluk, A., Marycz, K., 2014. Antimicrobial activity of low-pressure plasma treatment against selected foodborne bacteria and meat microbiota. Ann. Microbiol. 65, 1537-1546. doi:10.1007/s13213-014-0992-y

Williams, R.C., Sumner, S.S., Golden, D.A., 2005. Inactivation of Escherichia coli O157:H7 and Salmonella in Apple Cider and Orange Juice Treated with Combinations of Ozone, Dimethyl Dicarbonate, and Hydrogen Peroxide. J. Food Sci. 70, M197-M201. doi:10.1111/j.1365-2621.2005.tb07188.x

Zeraik, A.E., Nitschke, M., 2012. Influence of growth media and temperature on bacterial adhesion to polystyrene surfaces. Brazilian Arch. Biol. Technol. 55, 569-576. doi:10.1590/S1516-89132012000400012

Ziuzina, D., Han, L., Cullen, P.J., Bourke, P., 2015. Cold plasma inactivation of internalised bacteria and biofilms for Salmonella enterica serovar Typhimurium, Listeria monocytogenes and Escherichia coli. Int. J. Food Microbiol. 210, 53-61. doi:10.1016/j.ijfoodmicro.2015.05.019

Ziuzina, D., Patil, S., Cullen, P., Keener, K., Bourke, P., 2014. Atmospheric Cold Plasma Inactivation of Escherichia Coli, Salmonella Enterica Serovar Typhimurium and Listeria Monocytogenes Inoculated on Fresh Produce. doi:10.1016/j.fm.2014.02.007

(1)

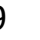

1

2

3


584

585

586

587

588

589

590

591

592

593

594

595

596

597

598

599

600

601

602

603

604

605

606

\section{Figure legends}

Figure 1: Experimental setup of DBD ACP (DIT120) cold plasma device

Figure 2: Plasma treatment at $80 \mathrm{kv}$ with $24 \mathrm{~h}$ and $1 \mathrm{~h}$ post treatment storage time with different treatment time of $15 \mathrm{~s}, 30 \mathrm{~s}$ and $60 \mathrm{~s}$. Vertical bars represent standard deviation.

$(\bullet)$ Untreated sample with 0h storage ( $\bullet$ ACP treatment after 1h PTST (घ) ACP treatment after 24h PTST

Figure 3: Effect of different ACP treatment time on B. thermosphacta grown in liquid meat model and PBS. Vertical bars represent standard deviation. ( $\mathbf{\Delta}$ ) ACP treated cells in PBS, $(\Delta)$ untreated cells in PBS ( $\square$ ) ACP treated cells in 3\% BE, ( $\square$ ) untreated cells in 3\% BE. Detection limit was $1 \log _{10} \mathrm{CFU} / \mathrm{ml}$

Figure 4: Biofilm formation of B. thermosphacta after $24 \mathrm{~h}, 48 \mathrm{~h} \& 72 \mathrm{~h}$ of incubation at $26^{\circ} \mathrm{C}$

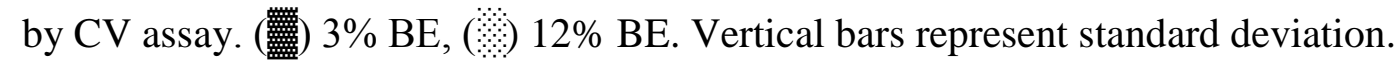

Figure 5: Media associated B. thermosphacta biofilm formation quantified by crystal violet assay after $48 \mathrm{~h}$ incubation at $26^{\circ} \mathrm{C}$.

Figure 6: Effect of ACP on B. thermosphacta $48 \mathrm{~h}$ biofilm in $12 \%$ beef extract, treated at 80 $\mathrm{kV}$ and assessed using plate count method. (匹) ACP treated, $(\bullet)$ untreated biofilm control. Vertical bars represent standard deviation. Limit of detection was $1 \mathrm{Log}$ CFU/ml.

Figure 7: Percentage of B. thermosphacta biofilm survival curves upon exposure to $80 \mathrm{kv}$ of ACP treatment based on XTT assay. ( $\bullet$ ACP treated biofilm, $(\bullet)$ untreated biofilm control. Vertical bars represent standard deviation.

Figure 8: Background micro flora of Lamb chop packed with $30 \% \mathrm{CO}_{2} \& 70 \% \mathrm{O}_{2}$ and treated with plasma at $80 \mathrm{kV}$ for 60 s for up to shelf life of 13 days. (•) untreated Control, ( $\square$ ) 60s ACP treated), dotted line indicate improper sealing. 
607 Figure 9(a): Effect of ACP treatment (1 min at $80 \mathrm{kV})$ on Lamb inoculated with $B$.

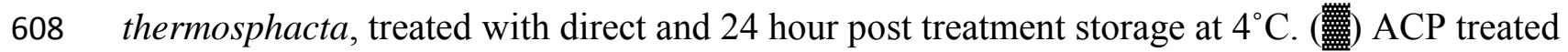
609 samples, (3) Control samples. Vertical bars indicate standard deviation.

610 Figure 9(b): $B$. thermosphacta inoculated on Lamb chop packaged with $70 \% \mathrm{O}_{2}$ and $30 \%$ $611 \mathrm{CO}_{2}$ concentration for period of 14 days, treated for $1 \mathrm{~min}$ at $80 \mathrm{kV}$ and stored at $4{ }^{\circ} \mathrm{C}$. ( $\bullet$ ) 612 untreated Control, (घ) 60s ACP treated)

613 Figure 10: DGGE image of bacterial 16s rDNA amplified from lamb samples, separated in a 614 polyacrylamide gel containing a gradient of 30-60\% denaturant 


\section{$\begin{array}{lll}618 & 7 & \text { Table legends }\end{array}$}

619 Table 1: Effect of ACP on B. thermosphacta inactivation at different voltage levels after $1 \mathrm{hr}$ 620 and 24h PTST in PBS

621 Table 2: B. thermosphacta inactivation efficacy at $80 \mathrm{kv}$ with different media after 24 post 622 storage treament

623 Table 3: In-package ozone and carbon monoxide concentration measured inside the sealed 624 trays after plasma treatment at $80 \mathrm{Kv}$. 


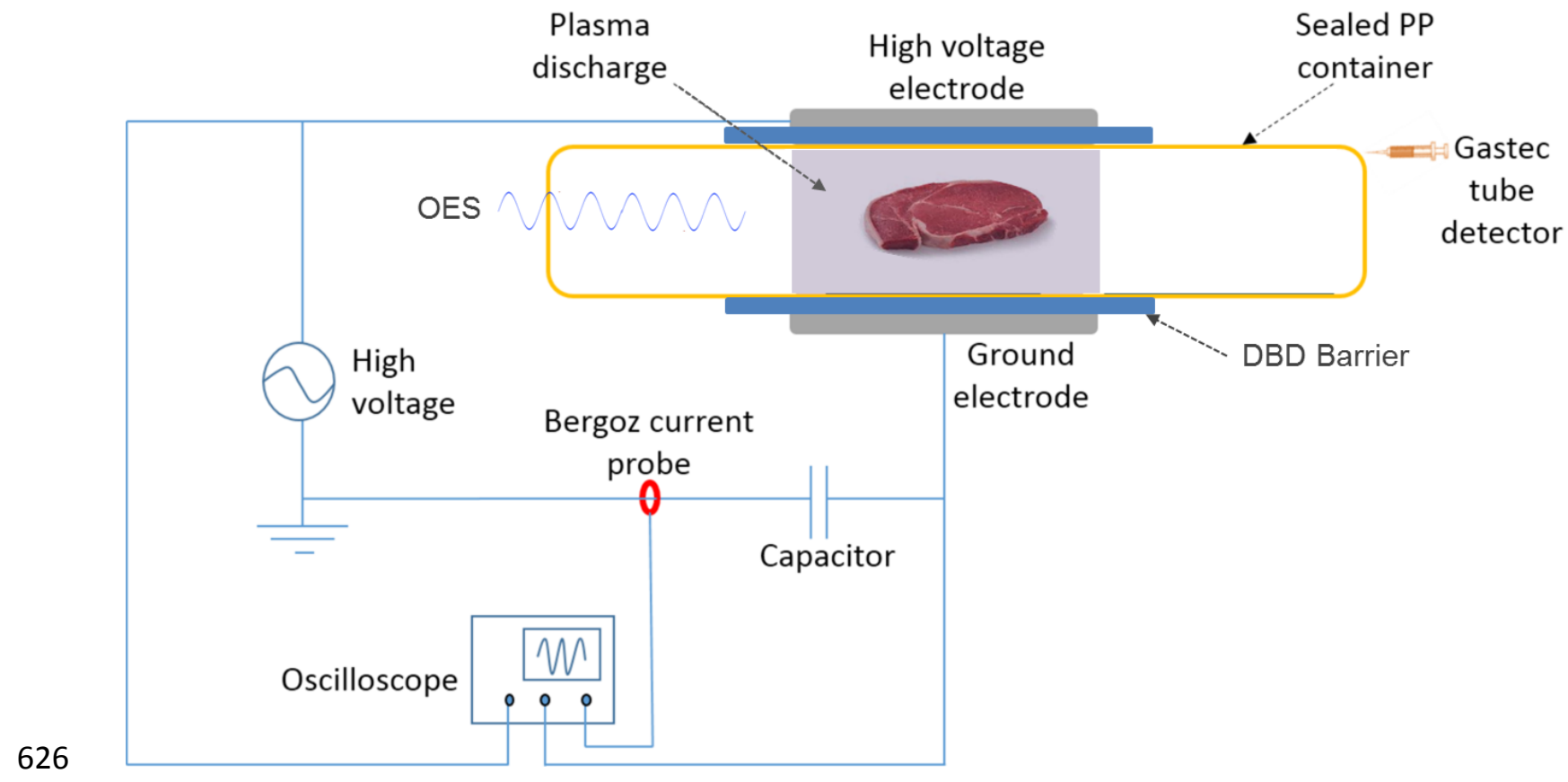

627

628

629

Figure 2:

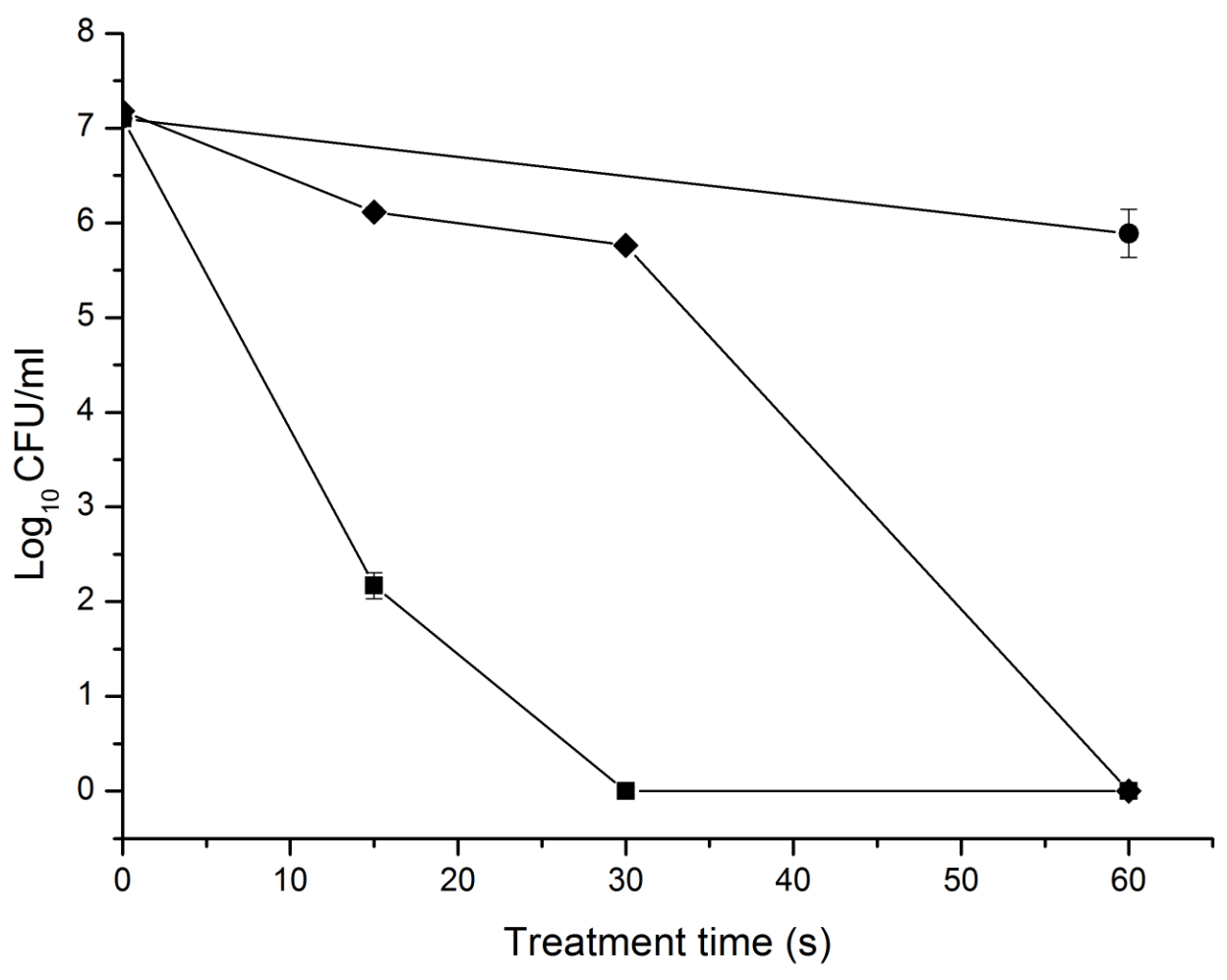

630 


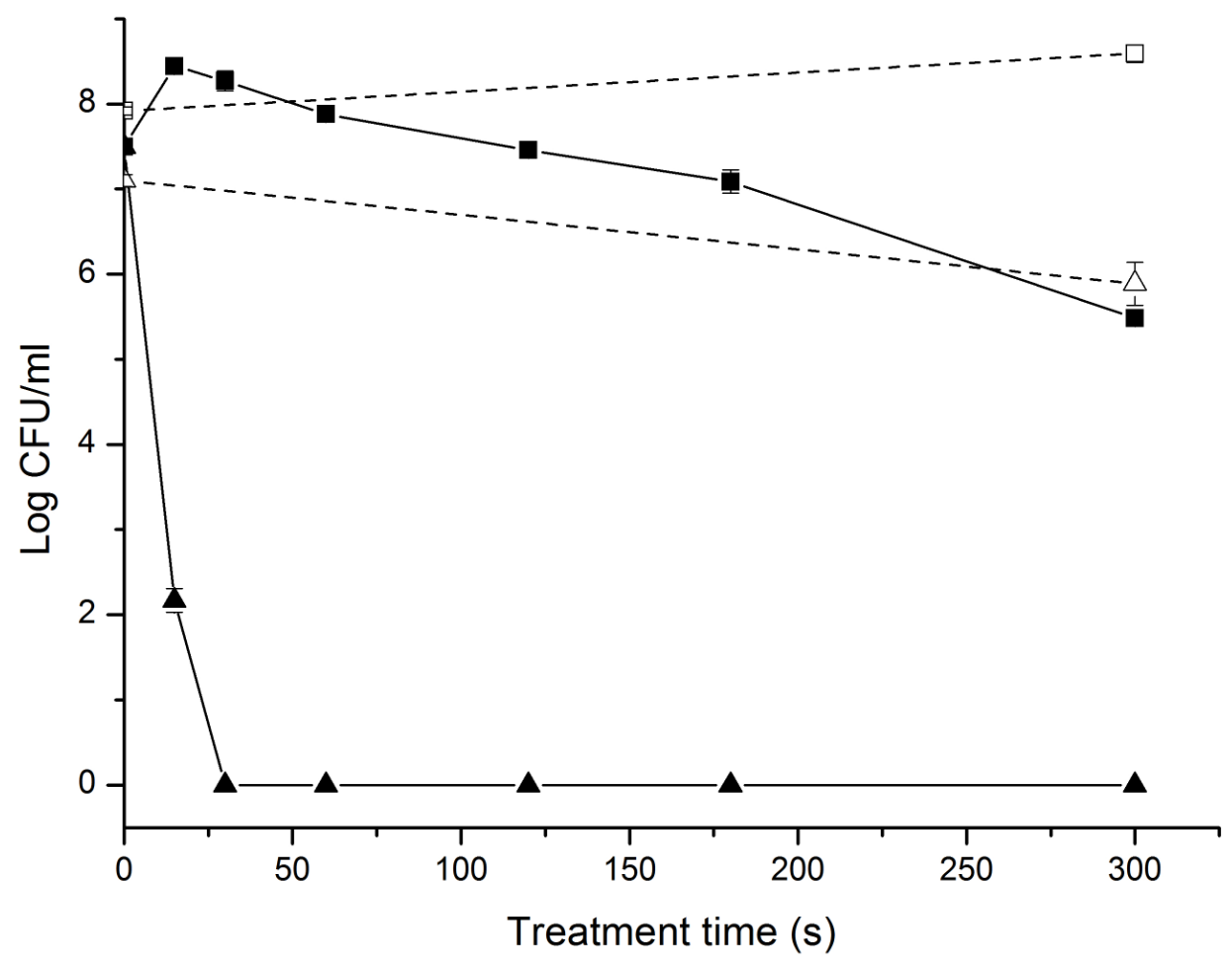

634

635 Figure 4:

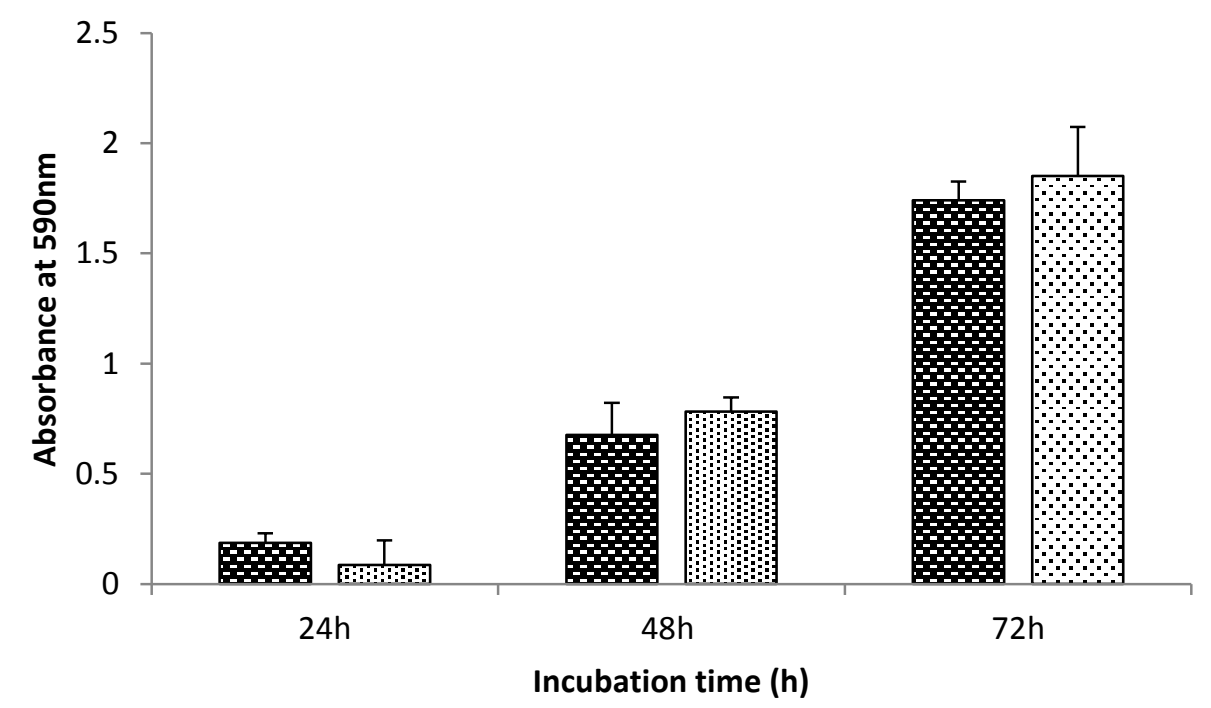

636

637

638

639 Figure 5: 


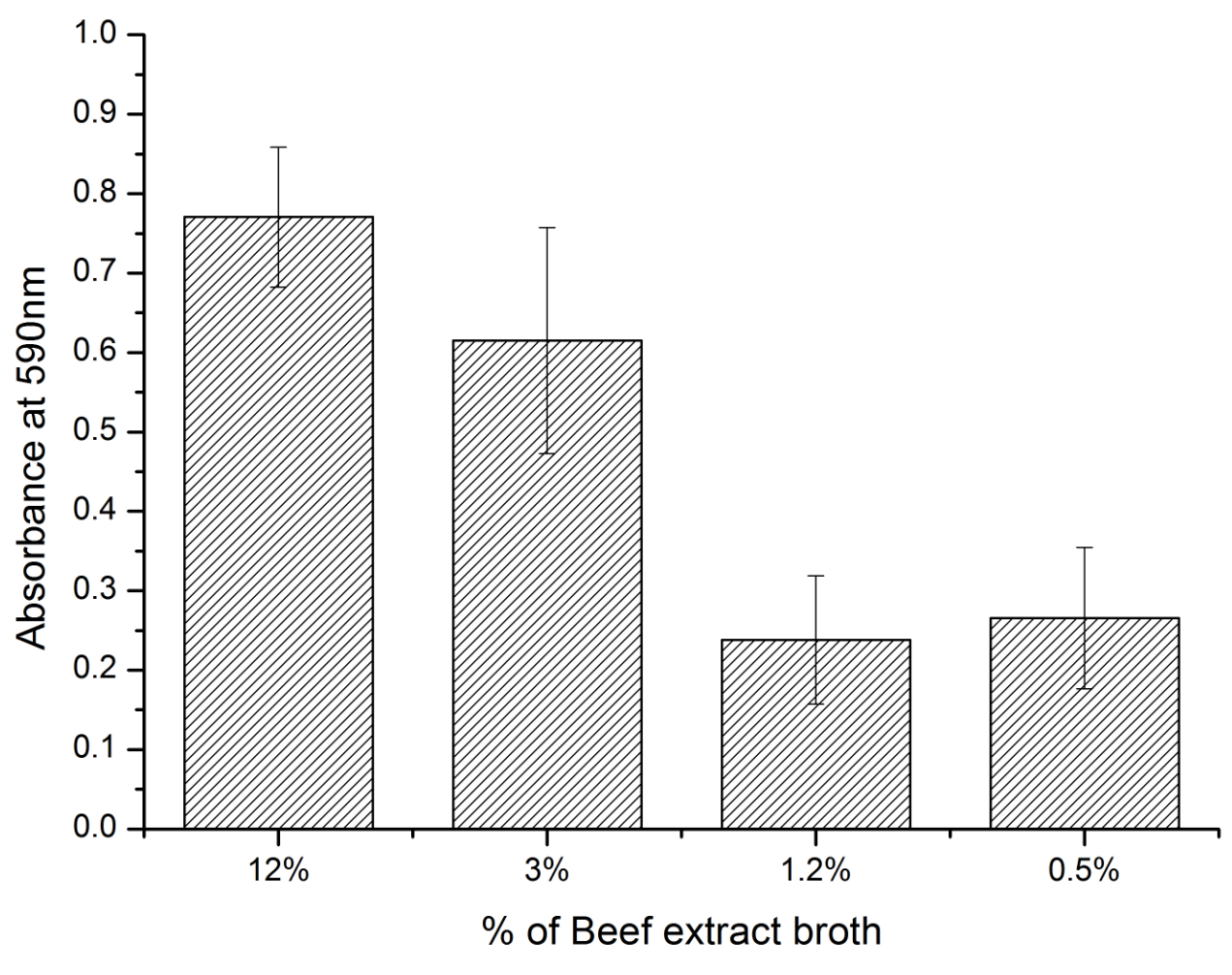

641

642

643

644

645

646

647

648

649

650

651

652

653

654 Figure 6: 


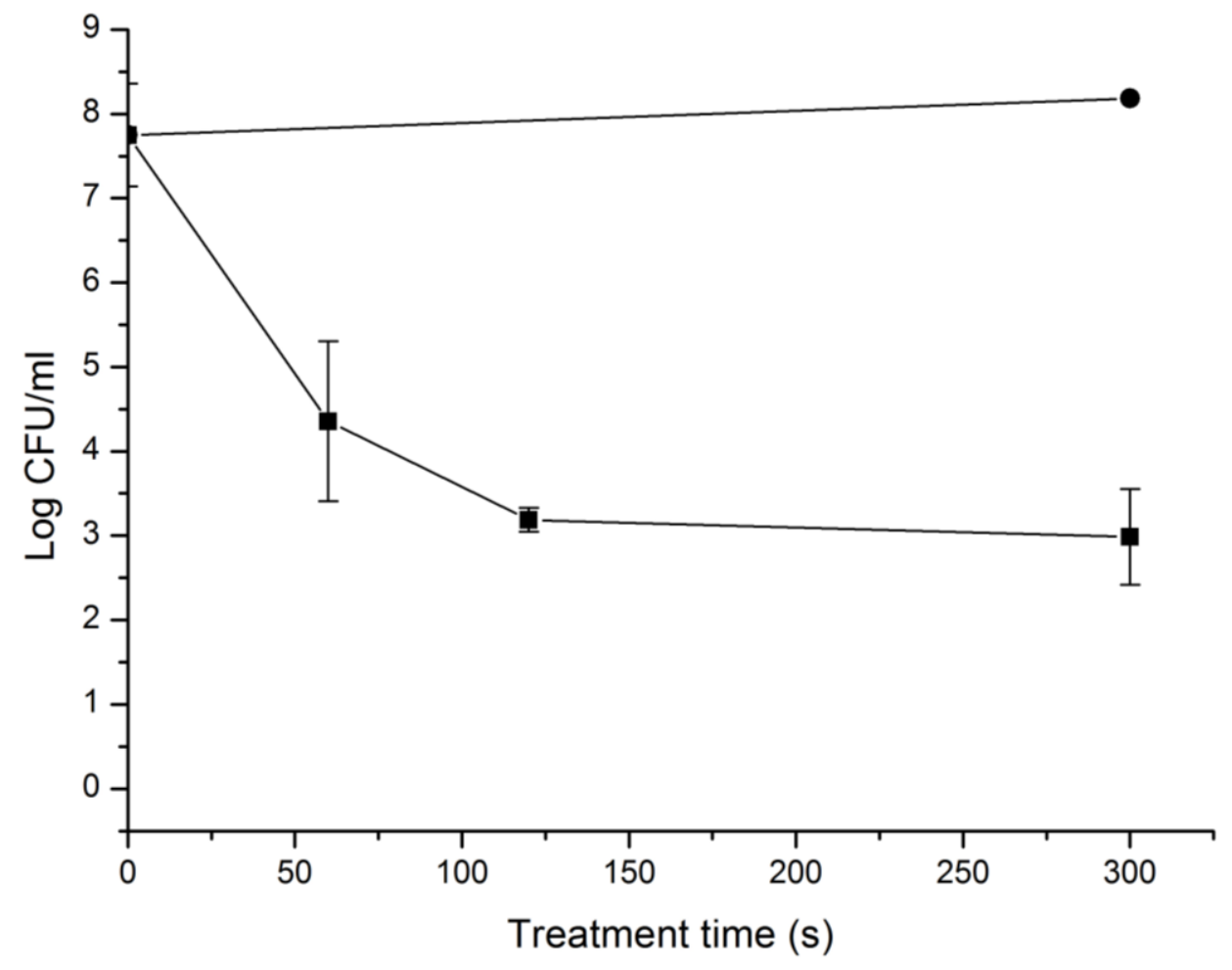

655

656 Figure 7:

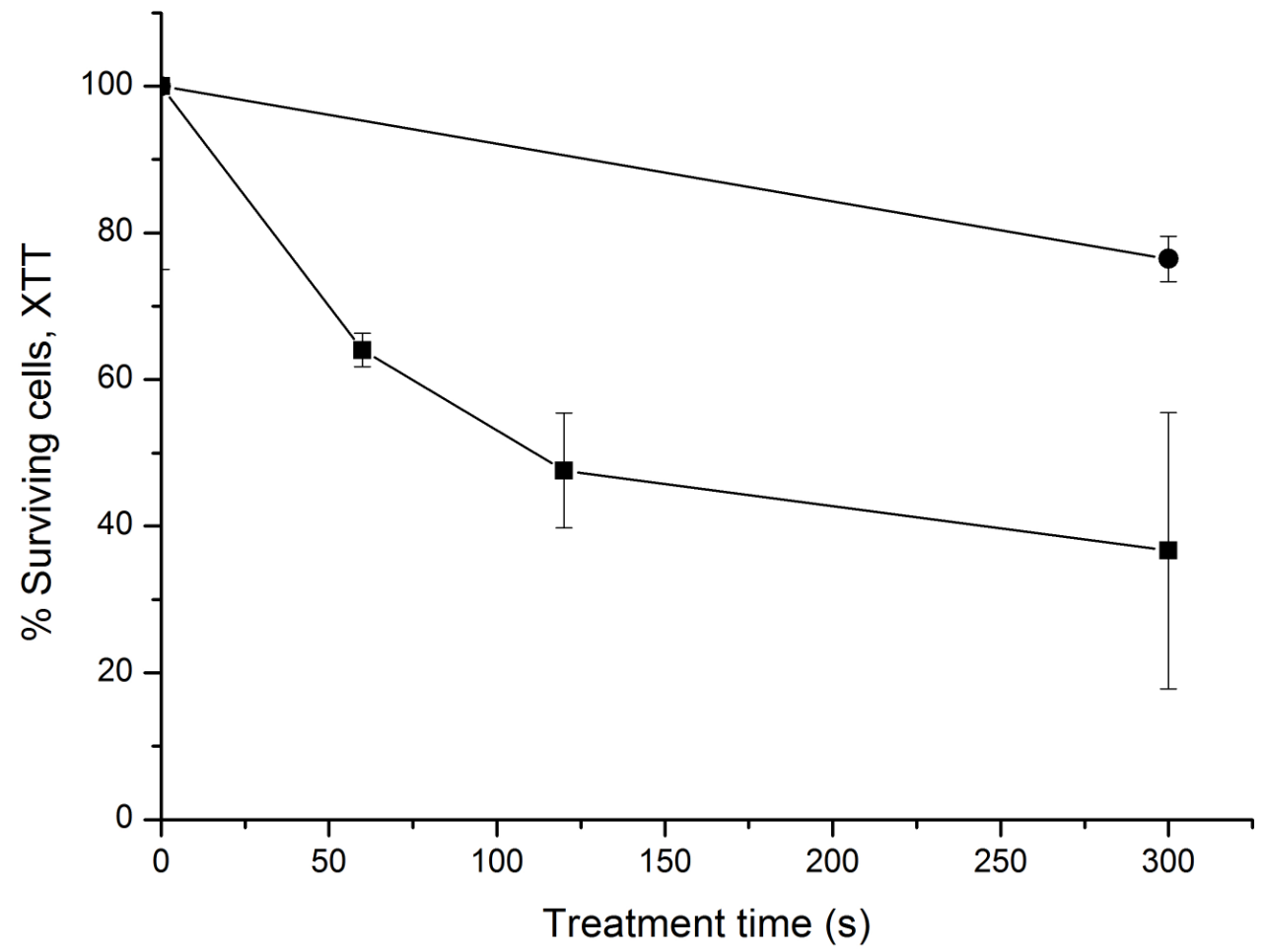

657

658 Figure 8: 


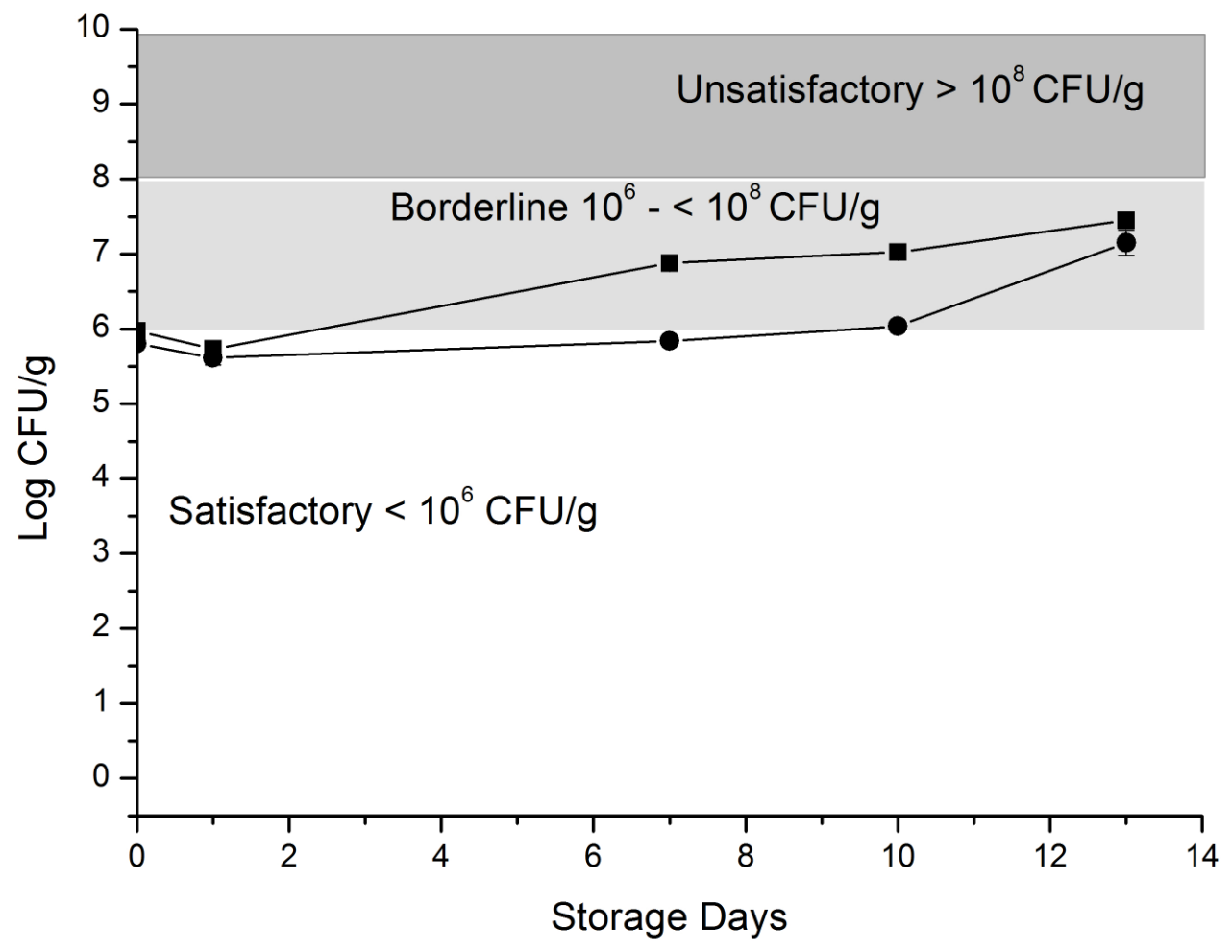

659 660 Figure 9(a):

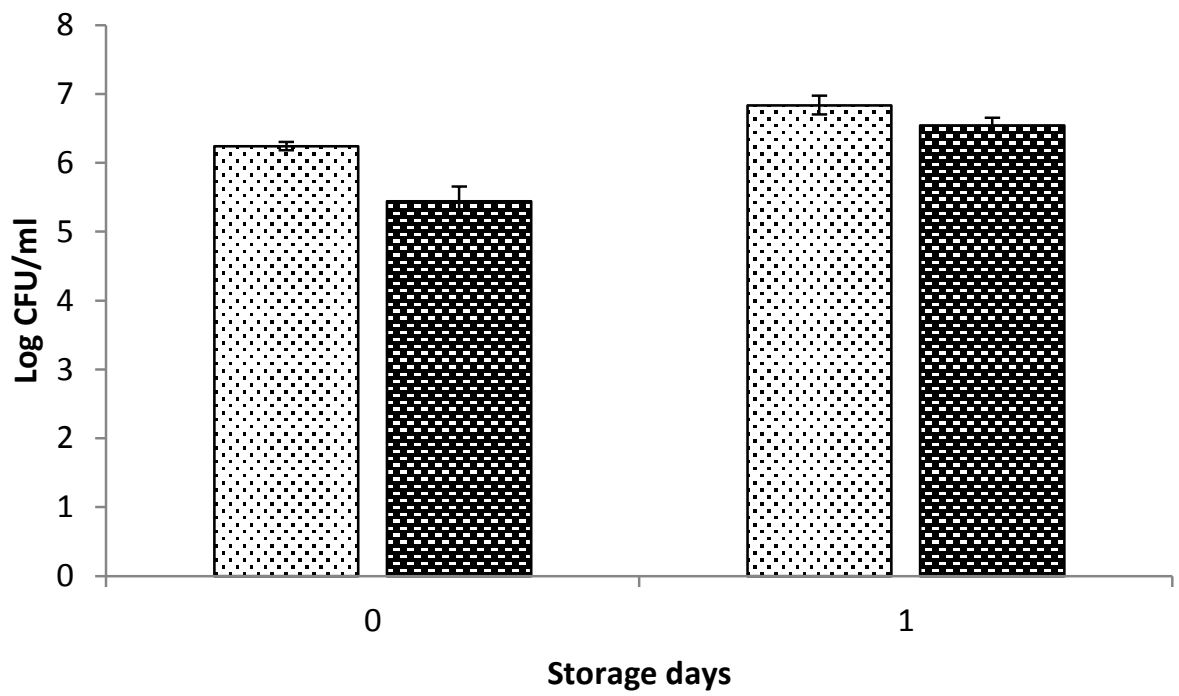

661

Figure 9(b): 


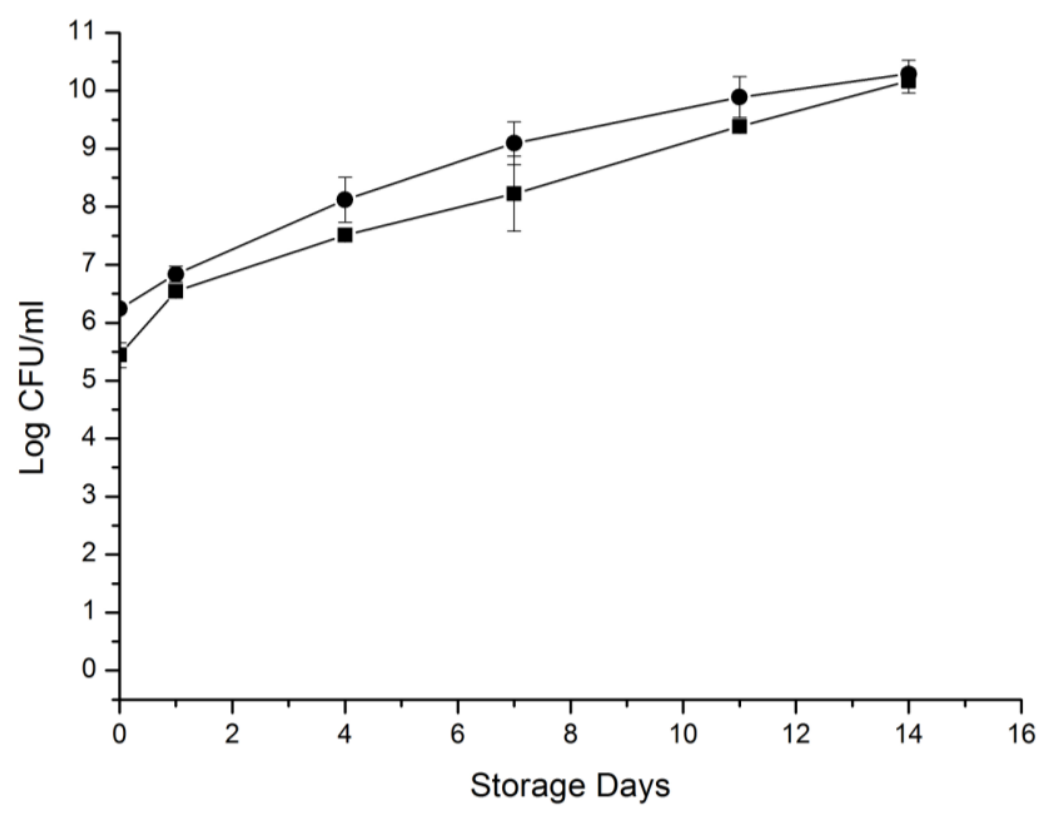

668 Figure 10:

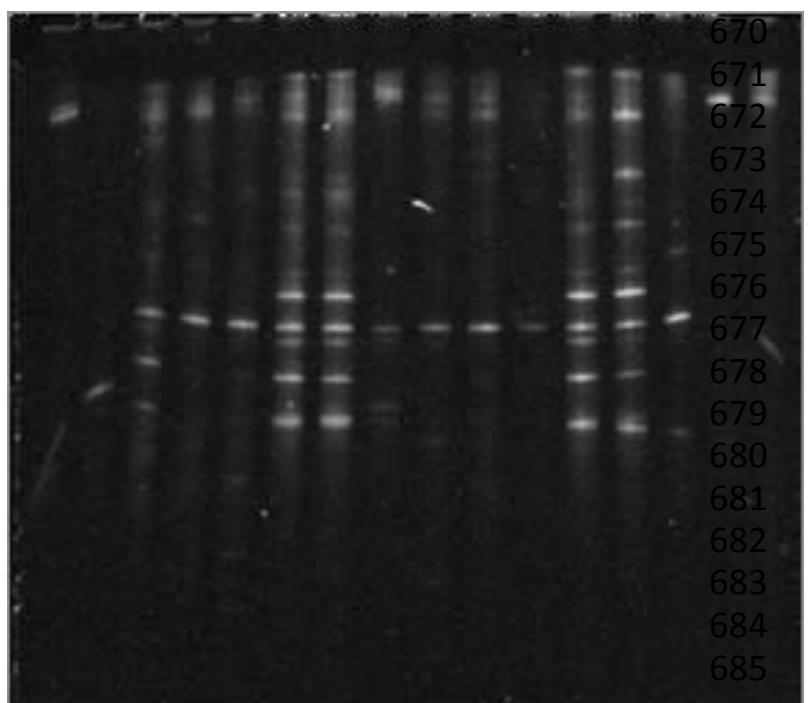

1 L. monocytogenes

2 E. coli

3 d0 control

4 d1 control

$5 \mathrm{~d} 4$ control

$6 \mathrm{~d} 7$ control

7 d13 control

8 Mixed standards

9 d0 treated

$10 \mathrm{~d} 1$ treated

$11 \mathrm{~d} 4$ treated

$12 \mathrm{~d} 7$ treated

$13 \mathrm{~d} 13$ treated

14 B. thermosphacta

15 S. aureus

16 C. jejuni 1146DF 
Table 1:

\begin{tabular}{|c|c|c|c|c|c|}
\hline \multirow[t]{2}{*}{$\begin{array}{c}\text { APPLIED } \\
\text { VOLTAGES }\end{array}$} & \multirow{2}{*}{$\begin{array}{c}\text { PLASMA } \\
\text { TREATMENT } \\
\text { TIME (S) }\end{array}$} & \multicolumn{2}{|c|}{$\begin{array}{l}\text { 1H POST } \\
\text { STORAGE }\end{array}$} & \multicolumn{2}{|c|}{$\begin{array}{l}\text { 24H POST } \\
\text { STORAGE }\end{array}$} \\
\hline & & $\begin{array}{c}\text { Cell } \\
\text { density } \\
\left(\log _{10}\right. \\
\text { CFU/ml) }\end{array}$ & SD* & $\begin{array}{c}\text { Cell } \\
\text { density } \\
\left(\log _{10}\right. \\
\text { CFU/ml) }\end{array}$ & SD* \\
\hline \multirow{6}{*}{$60 \mathrm{KV}$} & 0 & 7.184 & 0.02 & 7.10 & 0.06 \\
\hline & 15 & 6.95 & 0.04 & 4.56 & 0.12 \\
\hline & 30 & 6.54 & 0.06 & 0.0 & 0.0 \\
\hline & 60 & 6.21 & 0.11 & 0.0 & 0.0 \\
\hline & 120 & 4.99 & 0.18 & 0.0 & 0.0 \\
\hline & 300 & 0.0 & 0.0 & 0.0 & 0.0 \\
\hline \multirow{6}{*}{$70 \mathrm{KV}$} & 0 & 7.184 & 0.02 & 7.10 & 0.06 \\
\hline & 15 & 6.52 & 0.12 & 3.46 & 0.12 \\
\hline & 30 & 5.81 & 0.04 & 0.0 & 0.0 \\
\hline & 60 & 0.0 & 0.0 & 0.0 & 0.0 \\
\hline & 120 & 0.0 & 0.0 & 0.0 & 0.0 \\
\hline & 300 & 0.0 & 0.0 & 0.0 & 0.0 \\
\hline \multirow{6}{*}{$80 K V$} & 0 & 7.183 & 0.02 & 7.10 & 0.06 \\
\hline & 15 & 6.115 & 0.05 & 2.17 & 0.14 \\
\hline & 30 & 5.763 & 0.03 & 0.0 & 0.0 \\
\hline & 60 & 0.0 & 0.0 & 0.0 & 0.0 \\
\hline & 120 & 0.0 & 0.0 & 0.0 & 0.0 \\
\hline & 300 & 0.0 & 0.0 & 0.0 & 0.0 \\
\hline
\end{tabular}

688

689 
Table 2:

\begin{tabular}{cccc}
\hline Media & $\begin{array}{c}\text { Plasma } \\
\text { treatment } \\
\text { time (s) }\end{array}$ & $\begin{array}{c}\text { Cell } \\
\text { density } \\
\left(\mathbf{L o g}_{10}\right. \\
\text { CFU/ml) }\end{array}$ & SD* \\
\hline \multirow{3}{*}{ 3\% } & $\mathrm{C} 1$ & 7.81 & 0.05 \\
beef & 15 & 8.59 & 0.10 \\
extract & 30 & 8.44 & 0.07 \\
& 60 & 7.27 & 0.12 \\
& 120 & 7.46 & 0.05 \\
& 180 & 7.09 & 0.07 \\
PBS & 300 & 5.49 & 0.08 \\
\hline & $\mathrm{C} 1$ & 7.10 & 0.07 \\
& $\mathrm{C} 2$ & 5.89 & 0.25 \\
& 15 & 2.17 & 0.14 \\
& 30 & 0.00 & 0.00 \\
& 60 & 0.00 & 0.00 \\
& 120 & 0.00 & 0.00 \\
& 180 & 0.00 & 0.00 \\
& 300 & 0.00 & 0.00 \\
\hline
\end{tabular}

691 C1*: Control without storage

692 C2**: Control with 24h storage

693 Table 3:

694

695

696

697

\begin{tabular}{lcc}
\hline & \multicolumn{2}{c}{ Measurement time } \\
$\mathrm{t}=0 \mathrm{~h}$ & $\mathrm{t}=1 \mathrm{~h}$ \\
\hline Ozone- 1 min & & \\
Lamb & $1800 \mathrm{ppm}$ & $\mathrm{ND}$ \\
\hline $\begin{array}{c}\text { Carbon monoxide-1 min } \\
\text { Lamb }\end{array}$ & $\mathrm{NT}$ \\
\hline & $\mathrm{NT}$ \\
$* * \mathrm{ND}=$ non-detectable & not tested (if at a longer treatment time was non-detectable)
\end{tabular}

